\title{
2: $111597541-111640818$
}

National Cancer Institute

\section{Source}

National Cancer Institute. 2:111597541-111640818. NCI Thesaurus. Code C41763.

Physical location of BCL2L11_Gene 